\title{
UPAYA PERBAIKAN SIFAT FISIK SERAT RAYON VISKOSA SELAMA PENYIMPANAN MELALUI PENGGUNAAN HIDROGEN PEROKSIDA PADA PROSES PENYEMPURNAAN SERAT RAYON VISKOSA
}

\author{
Oleh : \\ Ika Natalia Mauliza dan Ikhwanul Muslim
}

\begin{abstract}
Bleaching process in the manufacture of viscose rayon fibers using $\mathrm{NaOCl}$ may result reduced degrees of whiteness and the brightness of the fiber during the storage period which is caused by the residual chlorine that is still attached to the fiber, so it made the process of using $\mathrm{H}_{2} \mathrm{O}_{2}$ to remove residual chlorine from the bleaching process. In this experiment used a variation of concentration of $\mathrm{H}_{2} \mathrm{O}_{2} 0 ; 0.2 ; 0.4$ and $0.6 \mathrm{~g} / \mathrm{l}$ at $\mathrm{pH}$, the working temperature of $50{ }^{\circ} \mathrm{C}$ with a conveyor speed of $3.75 \mathrm{~m} / \mathrm{min}$ and 3.2 meter length of the machine. The experiments does in the end of finishing process simultan with softening process. Fibers that have been dried and then tested the brightness, degree of white, tensile strength and elongation before and after storage (0 and 90 days of storage).

From the experimental results obtained that with increasing concentrations of $\mathrm{H}_{2} \mathrm{O}_{2}$, change of brightness, whiteness, tensile strength and elongation of viscose rayon fibers decreases. At $\mathrm{H}_{2} \mathrm{O}_{2}$ concentrations $0.4 \mathrm{~g} / \mathrm{l}$, the change of physical properties during storage is very small and still in accordance with the standards, the brightness decreased $0.11 \%$, whiteness decreased $0.43 \%$, dry and wet tensile strengths decreased respectively $0.73 \%$ and $0.15 \%$ and increase dry and wet elongation respectively $0.98 \%$ and $0.89 \%$.
\end{abstract}

\section{INTISARI}

Proses pengelantangan pada pembuatan serat rayon viskosa menggunakan $\mathrm{NaOCl}$ dapat mengakibatkan menurunnya derajat putih dan kecerahan serat selama masa penyimpanan yang disebabkan adanya sisa klor yang masih menempel pada serat, sehingga dilakukan proses menggunakan $\mathrm{H}_{2} \mathrm{O}_{2}$ untuk menghilangkan sisa klor dari proses pengelantangan. Dalam percobaan ini digunakan variasi konsentrasi $\mathrm{H}_{2} \mathrm{O}_{2} 0 ; 0,2 ; 0,4$ dan $0,6 \mathrm{~g} / \mathrm{l}$ pada $\mathrm{pH} 6$, suhu pengerjaan $50{ }^{\circ} \mathrm{C}$, kecepatan konveyor $3,75 \mathrm{~m} / \mathrm{menit}$ dan panjang mesin 3,2 meter. Pengerjaan dilakukan di akhir proses penyempurnaan serat, bersamaan dengan proses pelembutan. Serat yang telah kering kemudian diuji kecerahan, derajat putih, kekuatan tarik dan mulur sebelum dan sesudah penyimpanan (0 dan 90 hari penyimpanan).

Dari percobaan didapat hasil bahwa dengan meningkatnya konsentrasi $\mathrm{H}_{2} \mathrm{O}_{2}$, perubahan kecerahan, derajat putih, kekuatan tarik dan mulur serat rayon 
viskosa semakin berkurang. Pada konsentrasi $\mathrm{H}_{2} \mathrm{O}_{2} 0,4 \mathrm{~g} / \mathrm{l}$, perubahan sifat fisik selama penyimpanan sangat kecil dan masih sesuai dengan standar, kecerahan menurun $0,11 \%$, derajat putih $0,43 \%$, kekuatan tarik kering dan basah masingmasing sebesar $0,73 \%$ dan 0,15\% serta pertambahan mulur kering dan basah masing-masing sebesar $0,98 \%$ dan $0,89 \%$.

\section{PENDAHULUAN}

Serat rayon viskosa digunakan di seluruh bagian dunia sebagai salah satu serat sintetis dari polimer alam yang paling banyak digunakan selain kapas. Serat rayon menjadi primadona seiring dengan peningkatan kebutuhan kapas yang sulit dipenuhi.

Derajat putih, kecerahan, kekuatan tarik dan mulur merupakan sifat fisik yang menentukan kualitas serat rayon viskosa. Selama masa penyimpanan, sifat fisik tersebut seringkali mengalami perubahan berupa timbulnya warna kekuningan atau penurunan derajat putih dan kecerahan sehingga tidak sesuai dengan standar.

Pengukuran derajat putih dan kecerahan dilakukan setelah selesai proses atau saat serat akan dikemas. Serat yang telah dikemas kemudian disimpan di gudang sebelum dikirim ke konsumen. Lama penyimpanan rata-rata adalah 90 hari, dan selama penyimpanan tersebut muncul efek kekuningan pada serat. Untuk mencegah efek kekuningan pada serat maka digunakan $\mathrm{H}_{2} \mathrm{O}_{2}$ pada proses penyempurnaan serat. $\mathrm{H}_{2} \mathrm{O}_{2}$ ini menghilangkan sisa klor yang menempel pada serat yang berpotensi menurunkan derajat putih dan kecerahan serat selama penyimpanan.

Serat rayon viskosa adalah serat semi-sintetis karena tidak bisa dikategorikan serat alam atau serat buatan secara penuh. Bahan bakunya adalah pulp dengan kadar selulosa tinggi. Proses pembuatannya adalah dengan cara perendaman dalam larutan $\mathrm{NaOH} 18 \%$ membentuk alkali selulosa, setelah itu diperas kemudian dicabik-cabik untuk mendapatkan selulosa serbuk. Selulosa serbuk dimasukkan kedalam aging drum untuk diperam. Pemeraman bertujuan untuk menurunkan derajat polimerisasi. Setelah mencapai derajat polimerisasi yang diinginkan, selulosa direaksikan dengan $\mathrm{CS}_{2}$ untuk mengubah selulosa menjadi senyawa natrium selulosa xantat (mudah larut) selama 1,5 - 3 jam pada suhu $32{ }^{\circ} \mathrm{C}$. Bubur xantat hasil proses xantasi dilarutkan dengan $\mathrm{NaOH} 5-8 \%$ lalu diaduk menjadi larutan viskosa. Selanjutnya larutan viskosa dihomogenkan dan diaduk sehingga menjadi larutan viskosa yang lebih halus. Lalu dilakukan proses pematangan hingga mencapai ripening index 14 - 16 . Proses pematangan dilakukan bersama dengan proses penyaringan agar kotoran dan serat yang tidak larut tidak ikut dipintal. Kemudian dilanjutkan dengan proses penghilangan gelembung udara. 
Serat rayon dipintal menggunakan sistem wet spinning, yaitu dengan cara menyemprotkan larutan viskosa melalui lubang spinneret kemudian dimasukkan kedalam larutan koagulasi yang terdiri dari asam sulfat, natrium sulfat dan seng sulfat, kemudian dilewatkan ke rol-rol peregang untuk mendapatkan derajat orientasi yang diinginkan. Selanjutnya filamen dipotongpotong sesuai panjang stapel kemudian dilakukan proses penghilangan karbon disulfida yang dilanjutkan dengan proses penyempurnaan serat.

Proses penyempurnaan serat bertujuan untuk menghilangkan sisa-sisa larutan koagulasi dan belerang yang tertinggal dalam serat, memutihkan serat, serta memberikan efek pelemasan pada serat. Tahapan proses yang dilakukan adalah pencucian bebas asam, pencucian pertama, penghilangan belerang (desulfurisasi) menggunakan $\mathrm{NaOH}$, pencucian kedua, pengelantangan dengan $\mathrm{NaOCl}$, pencucian ketiga, pencucian akhir, pelembutan dan pengerjaan $\mathrm{H}_{2} \mathrm{O}_{2}$.

Proses pengelantangan serat rayon viskosa bertujuan untuk mendapatkan derajat putih serat sesuai dengan yang dikehendaki dan juga untuk menghilangkan kotoran. Proses pengelantangan dilakukan dengan menggunakan $\mathrm{NaOCl}$. Proses pengelantangan dilakukan dalam suasana asam dengan penambahan asam asetat. Pada proses pengelantangan dengan $\mathrm{NaOCl}$ terjadi reaksi sebagai berikut :

Hidrolisa $\mathrm{NaOCl}$ oleh air

$\mathrm{NaOCl}+\mathrm{H}_{2} \mathrm{O} \rightleftharpoons \mathrm{NaOH}+\mathrm{HOCl}$

Asam hipoklorit yang terjadi tidak stabil dan mudah terurai menurut reaksi

$\mathrm{HOCl} \longrightarrow \mathrm{HCl}+\mathrm{On}$

On yang dihasilkan akan memutihkan serat dengan cara mengoksidasi ikatan rangkap pada serat menjadi ikatan tunggal. $\mathrm{NaOCl}$ dapat terurai oleh asam kuat menjadi $\mathrm{HOCl}$ atau $\mathrm{Cl}_{2}$ tergantung dari banyaknya asam yang ekuivalen, seperti pada reaksi berikut ini :

$\mathrm{NaOCl}+\mathrm{HCl} \longrightarrow \mathrm{NaCl}+\mathrm{HOCl}$

$\mathrm{NaOCl}+2 \mathrm{HCl} \longrightarrow \mathrm{NaCl}+\mathrm{Cl}_{2}+\mathrm{H}_{2} \mathrm{O}$

$\mathrm{NaOH}$ yang terbentuk pada proses pengelantangan akan membantu proses penghilangan sisa belerang yang masih ada setelah proses desulfurisasi.

Adanya sisa klor pada serat rayon dapat menyebabkan kekuningan selama proses penyimpanan. Sisa klor dapat terserap oleh serat sehingga harus dilakukan proses penghilangan klor.

Proses penghilangan klor dilakukan dengan menggunakan $\mathrm{H}_{2} \mathrm{O}_{2}$. Diketahui $\mathrm{H}_{2} \mathrm{O}_{2}$ merupakan oksidator yang memiliki daya oksidasi yang lebih kecil dibandingkan zat pengelantang oksidator lain, sehingga memperkecil 
kemungkinan merusak serat. Larutan $\mathrm{H}_{2} \mathrm{O}_{2}$ mudah terurai menjadi uap air dan oksigen, terutama jika dipanaskan. Faktor-faktor yang mempengaruhi penguraian $\mathrm{H}_{2} \mathrm{O}_{2}$ yaitu pH (alkali), suhu, katalisator dan stabilisator. Pemilihan $\mathrm{H}_{2} \mathrm{O}_{2}$ pada proses pengerjaan lanjutan serat memiliki fungsi ganda, yakni selain berfungsi sebagai zat pengelantang, $\mathrm{H}_{2} \mathrm{O}_{2}$ tersebut juga berfungsi sebagai zat anti klor yang menghilangkan sisa-sisa larutan pengelantang yang tertinggal pada serat. Jika serat-serat selulosa mengandung sisa klor, maka kerusakan serat dapat disebabkan oleh terbentuknya $\mathrm{HCl}$ atau $\mathrm{HOCl}$ selama pengeringan atau penyimpanan. $\mathrm{H}_{2} \mathrm{O}_{2}$ dapat menghancurkan sisa-sisa larutan pengelantang pada serat selulosa dengan reaksi sebagai berikut :

$\mathrm{NaOCl}+\mathrm{H}_{2} \mathrm{O}_{2} \longrightarrow \mathrm{NaCl}+\mathrm{H}_{2} \mathrm{O}+\mathrm{O}_{2}$

Selain itu, $\mathrm{H}_{2} \mathrm{O}_{2}$ memiliki kemampuan untuk bereaksi dengan spesies non aromatik seperti struktur karbonil dan kuinon. $\mathrm{H}_{2} \mathrm{O}_{2}$ terdekomposisi menjadi anion perhidroksil $\left(\mathrm{OOH}^{-}\right)$yang merupakan oksidan lunak yang bereaksi terutama dengan gugus karbonil. Anion perhidroksil menyerang gugus karbonil terutama struktur kuinon dan menguraikannya menjadi senyawa yang tidak berwarna. (Senior dan Ragauskas, 1996)

Penguningan pada bahan tekstil merupakan perubahan arah warna menjadi kuning atau kecoklatan pada bahan tekstil putih maupun berwarna. Efek penguningan merupakan suatu degradasi warna yang kompleks karena terdiri dari berbagai jenis efek kuning maupun mekanisme terjadinya degradasi tersebut. Pada serat rayon viskosa, efek penguningan dapat terjadi karena adanya sisa belerang pada serat, adanya $\mathrm{HOCl}$ atau $\mathrm{Cl}_{2}$ yang dibebaskan dari $\mathrm{NaOCl}$ pada proses pengelantangan dan pengeringan serat pada suhu tinggi. Sebagai solusi, dilakukan pengerjaan dengan menggunakan $\mathrm{H}_{2} \mathrm{O}_{2}$ dengan konsentrasi bervariasi untuk mengetahui titik optimum konsentrasi $\mathrm{H}_{2} \mathrm{O}_{2}$ yang dapat digunakan pada proses produksi. Adapun parameter yang digunakan untuk mengukur hasil diantaranya derajat putih, derajat kuning, kecerahan serta kekuatan tarik dan mulur serat.

\section{PERCOBAAN}

Percobaan dilakukan mengikuti proses produksi dengan memvariasikan konsentrasi $\mathrm{H}_{2} \mathrm{O}_{2}$ dan parameter proses lainnya dikontrol untuk tetap stabil pada satu titik. Percobaan dilakukan pada serat rayon viskosa 1.2/38 HTB dengan kriteria sebagai berikut : Jenis serat "high tenacity", kilau serat "bright", panjang stapel $38 \mathrm{~mm}$, kehalusan 1,20 denier. Penyimpanan 90 hari dilakukan setelah serat selesai proses penyempurnaan.

Bahan baku serat rayon viskosa adalah :

1. Pulp kombinasi : hard wood : hard wood + soft wood $=65 \%: 35 \%$ 
2. Kondisi penyimpanan di laboratorium dengan suhu $(27 \pm 1)^{\circ} \mathrm{C}, \mathrm{RH}(65 \pm 1)$

$\%$ dan waktu selama 90 hari

Diagram alir percobaan sebagai berikut :

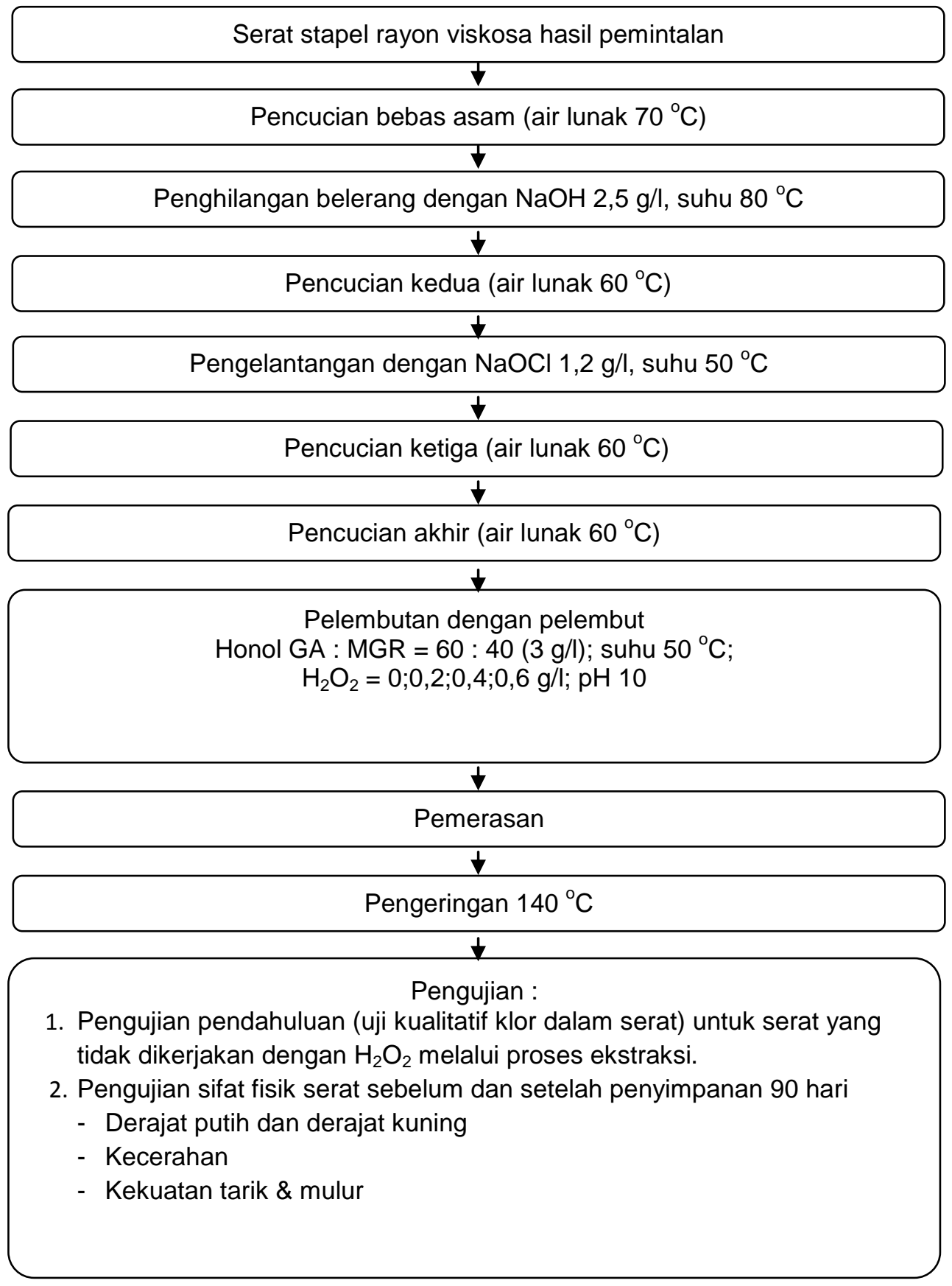


Estimasi waktu tiap proses adalah sama, yakni waktu proses di setiap chamber dengan kecepatan konveyor $3.75 \mathrm{~m} / \mathrm{menit}$ dan panjang chamber $3.2 \mathrm{~m}$. Dengan demikian diperoleh waktu tiap proses selama 52 detik.

Standar pengujian derajat putih, derajat kuning dan kecerahan mengacu pada SNI 08-0296-1989 menggunakan alat uji spektrofotometer (Vibrochrom FFR1 dan Vibrochrom FFR2) dengan prinsip pengujian membandingkan derajat putih, derajat kuning dan kecerahan sampel dengan standar yang telah ditentukan berdasarkan jenis sampel yang diuji, sedangkan untuk pengujian kekuatan tarik dan mulur menggunakan alat uji Vibroskop dan Vibrodyn yang mengacu pada SNI 08-0618-1989 dengan prinsip pengujian sehelai serat ditarik sampai putus, menggunakan alat dan cara yang telah ditetapkan, kemudian kekuatan tarik dan mulur serat dicatat.

\section{HASIL \& PEMBAHASAN}

Pengujian Pendahuluan

Hasil Pengujian pendahuluan adalah sebagai berikut :

Tabel 1. Hasil Pengujian Pendahuluan

\begin{tabular}{|c|l|c|}
\hline Tabung & \multicolumn{1}{|c|}{ Keterangan } & Kesimpulan \\
\hline Tabung a & $\begin{array}{l}\text { Larutan berwarna kuning dan terjadi } \\
\text { perubahan warna pada kertas KI-kanji } \\
\text { menjadi berwarna hitam kebiruan (ada } \\
\left.\mathrm{Cl}_{2}\right)\end{array}$ & Uji klor positif \\
\hline Tabung b & $\begin{array}{l}\text { Larutan berubah warna menjadi coklat } \\
\left(\mathrm{PbO}_{2}\right)\end{array}$ & Uji klor positif \\
\hline
\end{tabular}

Dari pengujian pendahuluan yang dimaksudkan untuk mendeteksi ada tidaknya sisa klor pada serat, diperoleh hasil positif artinya bahwa serat rayon hasil penyempurnaan masih mengandung sisa klor sehingga diperlukan proses penghilangan klor dengan $\mathrm{H}_{2} \mathrm{O}_{2}$.

Hasil pengujian lanjutan adalah sebagai berikut :

Tabel 2. Hasil Pengujian Derajat Putih, Kecerahan dan Derajat Kuning Serat Rayon

Viskosa Sebelum dan Setelah Penyimpanan

\begin{tabular}{|c|c|c|c|c|c|c|c|c|c|c|}
\hline $\begin{array}{c}\text { Konsent } \\
\text { rasi } \\
\begin{array}{c}\mathrm{H}_{2} \mathrm{O}_{2} \\
(\mathrm{~g} / \mathrm{l})\end{array}\end{array}$ & \multicolumn{4}{|c|}{ Derajat putih (\%) } & \multicolumn{4}{c|}{ Kecerahan (\%) } & \multicolumn{2}{c|}{ Derajat kuning } \\
\cline { 2 - 11 } & 90 Hari & Selisih & $\begin{array}{c}\text { Perubah } \\
\text { an (\%) }\end{array}$ & 0 Hari & $\begin{array}{c}90 \\
\text { Hari }\end{array}$ & Selisih & $\begin{array}{c}\text { Perubahan } \\
(\%)\end{array}$ & 0 Hari & 90 Hari \\
\hline 0 & 72,83 & 69,18 & 3,65 & 5,01 & 90,08 & 86,87 & 3,21 & 3,56 & $-1,07$ & $+0,13$ \\
\hline 0,2 & 73,07 & 71,62 & 1,45 & 1,98 & 90,15 & 88,63 & 1,52 & 1,69 & $-1,21$ & $-0,73$ \\
\hline 0,4 & 73,54 & 73,21 & 0,33 & 0,45 & 90,25 & 90,15 & 0,10 & 0,11 & $-1,33$ & $-1,28$ \\
\hline 0,6 & 74,04 & 73,72 & 0,32 & 0,43 & 90,32 & 90,23 & 0,09 & 0,10 & $-1,43$ & $-1,39$ \\
\hline
\end{tabular}


Tabel 3. Hasil Pengujian Kekuatan Tarik dan Mulur Serat Rayon Viskosa Sebelum dan Setelah Penyimpanan

\begin{tabular}{|c|c|c|c|c|c|c|c|c|}
\hline \multirow{3}{*}{$\begin{array}{c}\text { Konsentrasi } \\
\mathrm{H}_{2} \mathrm{O}_{2}(\mathrm{~g} / \mathrm{l})\end{array}$} & \multicolumn{8}{|c|}{ Kekuatan tarik (gram/denier) } \\
\hline & \multicolumn{4}{|c|}{ Kekuatan tarik kering } & \multicolumn{4}{|c|}{ Kekuatan tarik basah } \\
\hline & 0 Hari & $\begin{array}{l}90 \\
\text { Hari }\end{array}$ & Selisih & $\begin{array}{c}\text { Perubahan } \\
(\%)\end{array}$ & 0 Hari & $\begin{array}{c}90 \\
\text { Hari }\end{array}$ & Selisih & $\begin{array}{c}\text { Perubahan } \\
(\%)\end{array}$ \\
\hline 0 & 2,77 & 2,65 & 0,12 & 4,33 & 1,364 & 1,238 & 0,126 & 9,24 \\
\hline 0,2 & 2,76 & 2,70 & 0,06 & 2,17 & 1,340 & 1,278 & 0,062 & 4,63 \\
\hline 0,4 & 2,75 & 2,73 & 0,02 & 0,73 & 1,335 & 1,333 & 0,002 & 0,15 \\
\hline 0,6 & 2,75 & 2,74 & 0,01 & 0,36 & 1,334 & 1,333 & 0,001 & 0,07 \\
\hline \multirow{3}{*}{$\begin{array}{c}\text { Konsentrasi } \\
\mathrm{H}_{2} \mathrm{O}_{2}(\mathrm{~g} / \mathrm{l})\end{array}$} & \multicolumn{8}{|c|}{ Mulur (\%) } \\
\hline & \multicolumn{4}{|c|}{ Mulur kering } & \multicolumn{4}{|c|}{ Mulur basah } \\
\hline & 0 Hari & $\begin{array}{l}90 \\
\text { Hari }\end{array}$ & Selisih & $\begin{array}{c}\text { Perubahan } \\
(\%)\end{array}$ & 0 Hari & $\begin{array}{l}90 \\
\text { Hari }\end{array}$ & Selisih & $\begin{array}{c}\text { Perubahan } \\
(\%)\end{array}$ \\
\hline 0 & 20,370 & 22,470 & 2,100 & 10,31 & 22,825 & 25,455 & 2,630 & 11,52 \\
\hline 0,2 & 20,680 & 21,495 & 0,815 & 3,94 & 22,960 & 24,260 & 1,300 & 5,66 \\
\hline 0,4 & 20,870 & 21,075 & 0,205 & 0,98 & 23,110 & 23,315 & 0,205 & 0,89 \\
\hline 0,6 & 21,010 & 21,155 & 0,145 & 0,69 & 23,325 & 23,495 & 0,170 & 0,73 \\
\hline
\end{tabular}

\section{Derajat Putih dan Derajat Kuning}

Hasil pengujian derajat putih dan derajat kuning serat rayon viskosa sebelum dan setelah penyimpanan dapat dilihat pada Gambar 2 dan 3, berikut ini :

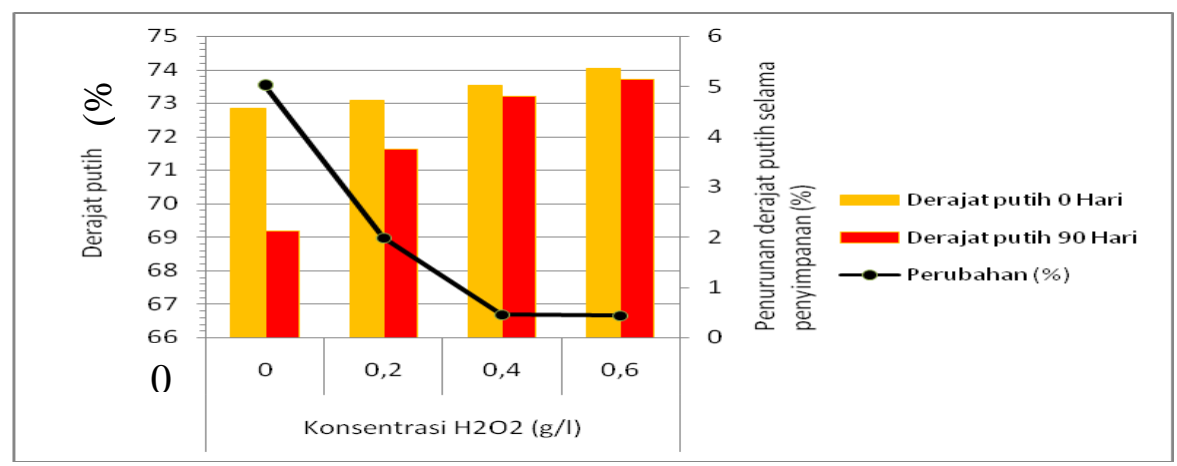

Gambar 2. Hubungan antara nilai dan \% perubahan derajat putih selama penyimpanan terhadap variasi konsentrasi $\mathrm{H}_{2} \mathrm{O}_{2}$ 


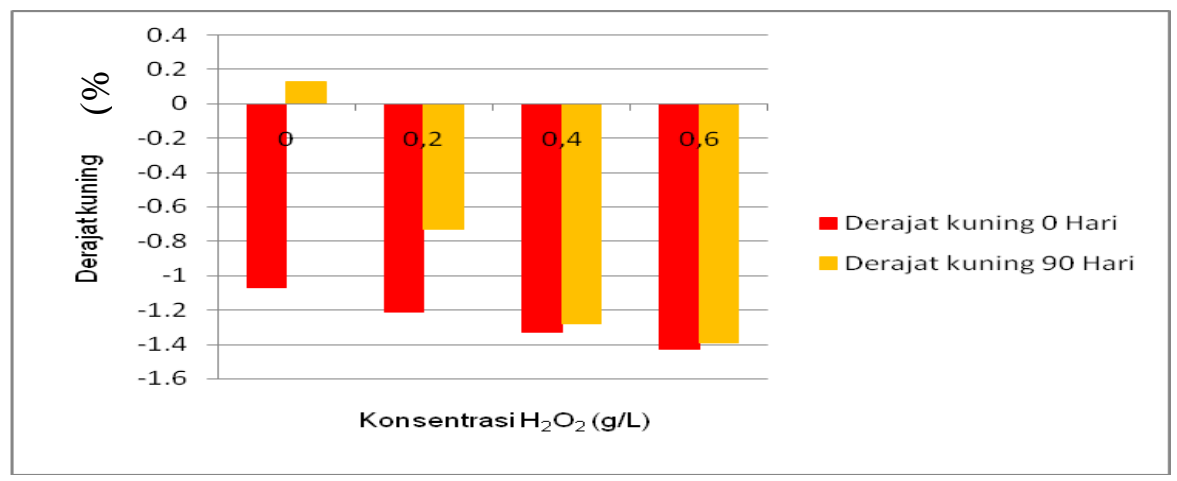

Gambar 3. Hubungan antara nilai dan \% perubahan derajat kuning selama penyimpanan terhadap variasi konsentrasi $\mathrm{H}_{2} \mathrm{O}_{2}$

Dari Gambar 2 dan 3 terlihat bahwa dengan penggunaan $\mathrm{H}_{2} \mathrm{O}_{2}$ pada proses penyempurnaan serat mengakibatkan derajat putih dan derajat kuning serat rayon lebih stabil selama penyimpanan. Penurunan derajat putih dan kenaikan derajat kuning yang paling besar terjadi pada serat yang tidak dikerjakan dengan $\mathrm{H}_{2} \mathrm{O}_{2}$ yakni sebesar $5,01 \%$ untuk penurunan derajat putihnya. Seiring penambahan konsentrasi $\mathrm{H}_{2} \mathrm{O}_{2}$, penurunan derajat putih dan kenaikan derajat kuningnya semakin berkurang terutama pada konsentrasi $\mathrm{H}_{2} \mathrm{O}_{2}$ $0,4 \mathrm{~g} / \mathrm{L}$ dan $0,6 \mathrm{~g} / \mathrm{L}$ yakni masing-masing $0,45 \%$ dan $0,43 \%$. Penurunan derajat putih dan kenaikan derajat kuning serat rayon viskosa yang terjadi selama penyimpanan disebabkan oleh adanya sisa klor dan larutan $\mathrm{NaOCl}$ di serat. Sisa klor dan larutan $\mathrm{NaOCl}$ tersebut selama penyimpanan bereaksi dengan uap air membentuk asam. Asam yang terbentuk akan menghidrolisa ikatan glukosida dalam rantai selulosa membentuk hidroselulosa yang dapat menimbulkan efek penguningan. Adanya sisa klor pada serat yang tidak kerjakan dengan $\mathrm{H}_{2} \mathrm{O}_{2}$ diperkuat dengan hasil uji kualitatif kandungan klor yang menunjukkan hasil positif. Dengan adanya $\mathrm{H}_{2} \mathrm{O}_{2}$, sisa klor dan $\mathrm{NaOCl}$ yang masih ada dalam serat bereaksi dengan $\mathrm{H}_{2} \mathrm{O}_{2}$ membentuk senyawa klor yang mudah larut, air dan molekul oksigen. Senyawa klor yang terbentuk selama reaksi akan larut dan mengalir dengan sirkulasi larutan $\mathrm{H}_{2} \mathrm{O}_{2}$.

Selain itu $\mathrm{H}_{2} \mathrm{O}_{2}$ memiliki kemampuan untuk bereaksi dengan spesies non aromatik seperti struktur karbonil dan kuinon. $\mathrm{H}_{2} \mathrm{O}_{2}$ terdekomposisi menjadi anion perhidroksil $\left(\mathrm{OOH}^{-}\right)$yang merupakan oksidan lunak yang bereaksi terutama dengan gugus karbonil. Anion perhidroksil menyerang gugus karbonil terutama struktur kuinon dan menguraikannya menjadi senyawa yang tidak berwarna. Akibatnya derajat putih, derajat kuning dan kecerahan relatif lebih stabil dengan penambahan $\mathrm{H}_{2} \mathrm{O}_{2}$.

Semakin besar konsentrasi $\mathrm{H}_{2} \mathrm{O}_{2}$, semakin banyak $\mathrm{H}_{2} \mathrm{O}_{2}$ yang bereaksi dengan sisa klor dan $\mathrm{NaOCl}$ sehingga derajat putih dan derajat kuningnya lebih stabil selama penyimpanan. Titik optimum dicapai pada konsentrasi $\mathrm{H}_{2} \mathrm{O}_{2} \mathrm{O}, 4 \mathrm{~g} / \mathrm{l}$. 


\section{Kecerahan}

Nilai kecerahan dan penurunan kecerahan pada serat rayon viskosa hasil pengujian dapat dilihat pada Gambar 4 berikut ini :

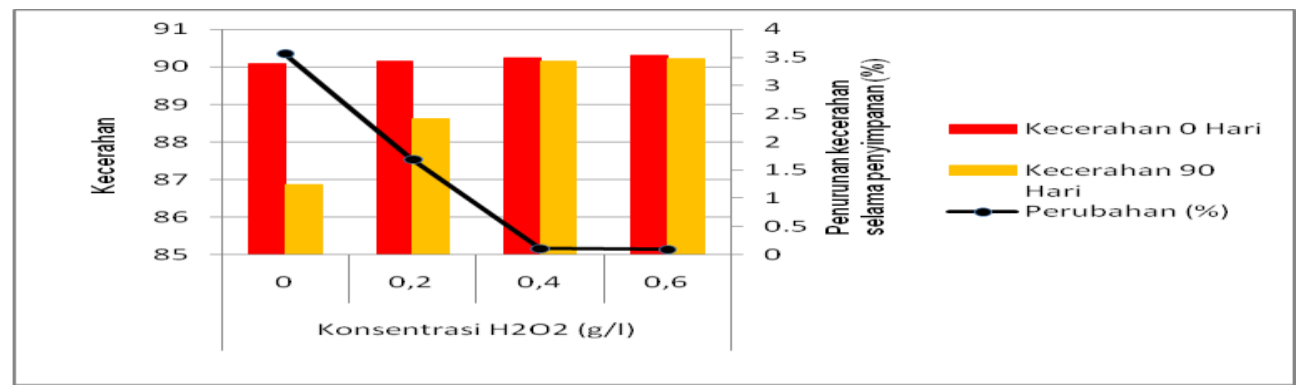

Gambar 4. Hubungan antara nilai dan \% perubahan kecerahan selama penyimpanan terhadap variasi konsentrasi $\mathrm{H}_{2} \mathrm{O}_{2}$

Pada grafik diatas terlihat bahwa dengan penggunaan $\mathrm{H}_{2} \mathrm{O}_{2}$ pada proses penyempurnaan serat mengakibatkan penurunan kecerahan serat semakin berkurang seiring dengan penambahan konsentrasi $\mathrm{H}_{2} \mathrm{O}_{2}$. Penurunan kecerahan terbesar terjadi pada serat yang tidak dikerjakan dengan $\mathrm{H}_{2} \mathrm{O}_{2}$, yakni sebesar $3,56 \%$ sedangkan penurunan kecerahan terkecil berada pada area konsentrasi $\mathrm{H}_{2} \mathrm{O}_{2} 0,4 \mathrm{~g} / \mathrm{L}$ dan $0,6 \mathrm{~g} / \mathrm{L}$ masing-masing sebesar $0,11 \%$ dan $0,10 \%$. Penurunan kecerahan ini terjadi karena adanya sisa klor yang tidak tercuci yang akan menyebabkan warna serat menjadi kekuningan selama penyimpanan sehingga warna serat akan tampak lebih suram. Hal ini salah satunya terjadi karena sifat klor sendiri yang berwarna kuning. Selain itu, sisa $\mathrm{NaOCl}$ yang tidak berhasil dihilangkan akan terurai membentuk asam yang yang selama penyimpanan akan menambah efek kekuningan yang terjadi sehingga serat menjadi lebih suram. Asam yang terbentuk akan menghidrolisa molekul selulosa menyebabkan rantai molekul selulosa menjadi lebih pendek dan tidak rata sehingga cenderung lebih mudah membentuk bagian amorf. Bagian amorf dalam serat yang semakin banyak menyebabkan penurunan kilau serat sehingga serat menjadi lebih suram. Dengan penggunaan $\mathrm{H}_{2} \mathrm{O}_{2}$, sisa-sisa klor yang terserap oleh serat terlebih dahulu bereaksi dengan $\mathrm{H}_{2} \mathrm{O}_{2}$ membentuk senyawa klor yang mudah larut, air dan molekul oksigen. Semakin banyak $\mathrm{H}_{2} \mathrm{O}_{2}$ yang digunakan, maka semakin banyak $\mathrm{H}_{2} \mathrm{O}_{2}$ yang bereaksi dengan sisa-sisa klor dan larutan $\mathrm{NaOCl}$, sehingga kecerahan serat menjadi lebih stabil selama penyimpanan.

\section{Kekuatan Tarik dan Mulur}

Hasil pengujian kekuatan tarik pada kondisi basah dan kering beserta perubahannya selama penyimpanan dapat dilihat pada Gambar 5 berikut ini : 


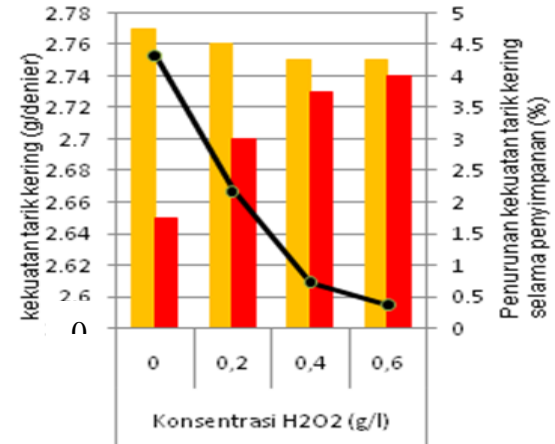

(a)
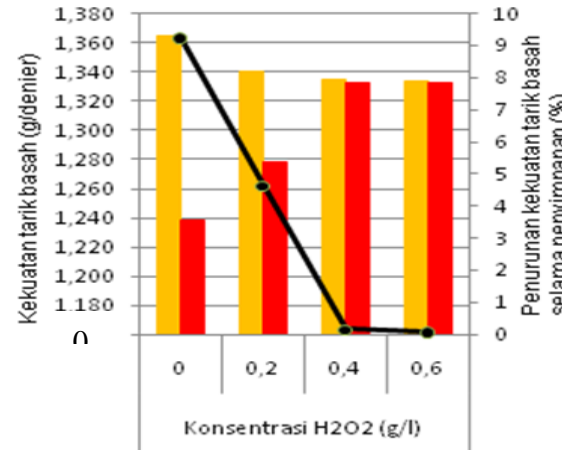

(b)

Gambar 5. Hubungan antara nilai dan \% perubahan kekuatan tarik kering (a)

dan basah (b) selama penyimpanan terhadap variasi konsentrasi $\mathrm{H}_{2} \mathrm{O}_{2}$

Berdasarkan grafik pada Gambar 5 di atas yang menunjukkan hubungan antara konsentrasi $\mathrm{H}_{2} \mathrm{O}_{2}$ dengan kekuatan tarik kering maupun basah, serta nilai penurunan kekuatan tarik terlihat bahwa penurunan kekuatan tarik serat rayon viskosa yang dikerjakan dengan variasi konsentrasi $\mathrm{H}_{2} \mathrm{O}_{2}$ hanya sedikit. Bahkan pada serat yang dikerjakan dengan $\mathrm{H}_{2} \mathrm{O}_{2} \quad 0,4 \mathrm{~g} / \mathrm{L}$ dan $0,6 \mathrm{~g} / \mathrm{L}$ perubahan yang terjadi hanya $0,73 \%$ dan $0,36 \%$ pada kondisi kering serta $0,15 \%$ dan $0,07 \%$ pada kondisi basah. Hal ini berarti bahwa penggunaan $\mathrm{H}_{2} \mathrm{O}_{2}$ pada range konsentrasi tersebut tidak terlalu berpengaruh terhadap kekuatan tarik kering maupun basah serat rayon viskosa. Efek penurunan kekuatan tarik yang sangat kecil tersebut merupakan salah satu kelebihan yang dihasilkan oleh pengerjaan serat rayon viskosa dengan $\mathrm{H}_{2} \mathrm{O}_{2}$, yakni meskipun $\mathrm{H}_{2} \mathrm{O}_{2}$ merupakan oksidator, tetapi efek penurunan kekuatan tarik yang terjadi hanya sedikit. Hal ini terjadi karena daya oksidasi $\mathrm{H}_{2} \mathrm{O}_{2}$ relatif lebih rendah dibandingkan $\mathrm{NaOCl}$ sehingga kerusakan serat akibat oksiselulosa akan lebih kecil. Pada grafik juga terlihat bahwa penurunan kekuatan tarik serat rayon yang tidak dikerjakan dengan $\mathrm{H}_{2} \mathrm{O}_{2}$ lebih tinggi dibandingkan dengan yang dikerjakan dengan $\mathrm{H}_{2} \mathrm{O}_{2}$, yakni sebesar 4,33\% untuk kekuatan tarik kering dan 9,24\% untuk kekuatan tarik basah. Hal ini terjadi karena pada serat yang tidak dikerjakan dengan $\mathrm{H}_{2} \mathrm{O}_{2}$ masih terdapat sisa klor dari proses pengelantangan dengan $\mathrm{NaOCl}$ yang tidak berhasil dihilangkan dengan pencucian. Klor yang masih tersisa dalam serat selama penyimpanan akan bereaksi dengan uap air membentuk asam $\mathrm{HCl}$ dan $\mathrm{HOCl}$ yang akan menghidrolisa rantai glukosida dari molekul selulosa menyebabkan rantai molekul selulosa menjadi lebih pendek dan tidak rata sehingga ikatan antar molekul serat menjadi lemah, akibatnya kekuatan tarik serat semakin menurun selama penyimpanan. Pada serat yang dikerjakan dengan $\mathrm{H}_{2} \mathrm{O}_{2}$, sisa klor bereaksi dengan $\mathrm{H}_{2} \mathrm{O}_{2}$ sehingga menghindari terbentuknya senyawa asam selama penyimpanan. Semakin banyak $\mathrm{H}_{2} \mathrm{O}_{2}$ yang ditambahkan, penurunan kekuatan tarik serat semakin kecil karena sisa klor yang bereaksi dengan $\mathrm{H}_{2} \mathrm{O}_{2}$ semakin banyak dan kemungkinan terbentuknya asam selama penyimpanan semakin kecil sehingga kekuatan tarik selama 
penyimpanan menjadi lebih stabil. Selain itu, asam yang berpotensi menurunkan kekuatan tarik serat dapat berasal dari adanya sisa belerang yang jika bereaksi dengan uap air akan membentuk asam sulfat. Namun pada serat yang dikerjakan dengan $\mathrm{H}_{2} \mathrm{O}_{2}$, belerang yang tersisa akan bereaksi dengan $\mathrm{H}_{2} \mathrm{O}_{2}$ sehingga memperkecil kemungkinan terjadinya hidroselulosa, akibatnya kekuatan tarik serat menjadi lebih stabil selama penyimpanan.

Hasil pengujian mulur kering dan basah serat rayon viskosa yang tidak maupun dikerjakan dengan $\mathrm{H}_{2} \mathrm{O}_{2}$ dapat dilihat pada Gambar 6 berikut ini :

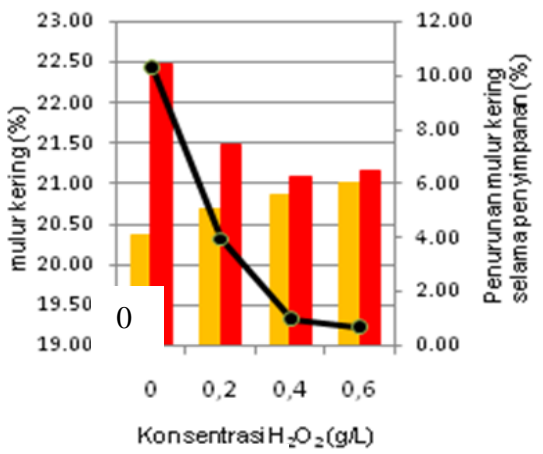

(a)

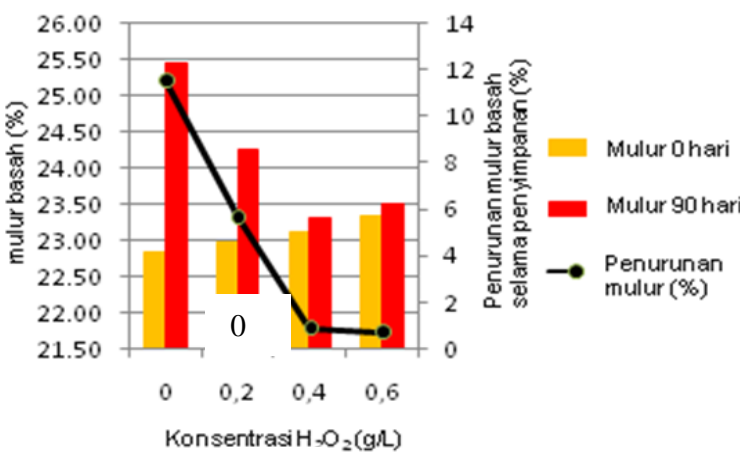

(b)

Gambar 6. Hubungan antara nilai dan \% perubahan mulur kering (a) dan basah (b) selama penyimpanan terhadap variasi konsentrasi $\mathrm{H}_{2} \mathrm{O}_{2}$

Pada grafik yang terdapat pada Gambar 6 menunjukkan hubungan antara konsentrasi $\mathrm{H}_{2} \mathrm{O}_{2}$ dengan mulur serat dan penurunan mulur terlihat bahwa pada serat yang tidak dikerjakan dengan $\mathrm{H}_{2} \mathrm{O}_{2}$ terjadi pertambahan mulur sebanyak $10,31 \%$ untuk mulur kering dan $11,52 \%$ untuk mulur basah selama penyimpanan. Hal ini terjadi karena pada serat tersebut masih ada sisa klor dalam serat yang selama masa penyimpanan membentuk asam yang akan menghidrolisa molekul serat menjadi lebih pendek. Rantai molekul pendek dalam serat membentuk bagian amorf yang akan berpengaruh pada saat penarikan pada pengujian mulur, dimana bagian amorf akan terlebih dahulu membentuk bagian yang lurus, kemudian dilanjutkan bersama-sama dengan bagian kristalin. Dengan demikian, mulur serat akan bertambah setelah penyimpanan. Pada serat yang dikerjakan dengan $\mathrm{H}_{2} \mathrm{O}_{2}$, perubahan mulur berkurang seiring kenaikan konsentrasi $\mathrm{H}_{2} \mathrm{O}_{2}$ terutama pada penggunaan $\mathrm{H}_{2} \mathrm{O}_{2}$ sebanyak 0,4 g/L dan 0,6 g/L yakni masing-masing sebesar 0,98\% dan 0,69\% untuk mulur kering dan $0,89 \%$ dan $0,73 \%$ untuk mulur basah. Hal ini terjadi karena sisa klor terlebih dahulu bereaksi dengan $\mathrm{H}_{2} \mathrm{O}_{2}$ sehingga memperkecil terbentuknya asam selama penyimpanan. Akibatnya, mulur serat lebih stabil selama penyimpanan. 


\section{KESIMPULAN}

Berdasarkan hasil percobaan dan pengujian terhadap serat rayon viskosa dengan menggunakan variasi konsentrasi $\mathrm{H}_{2} \mathrm{O}_{2}$ pada proses penyempurnaan serat, dapat ditarik kesimpulan sebagai berikut :

1. Penggunaan $\mathrm{H}_{2} \mathrm{O}_{2}$ pada proses penyempurnaan serat berpengaruh terhadap ketahanan sifat derajat putih, kecerahan, kekuatan tarik dan mulur serat rayon viskosa selama penyimpanan.

2. Penurunan derajat putih, kecerahan dan kekuatan tarik serat rayon viskosa selama penyimpanan berkurang seiring penambahan konsentrasi $\mathrm{H}_{2} \mathrm{O}_{2}$ pada proses penyempurnaan serat.

3. Perubahan mulur serat rayon viskosa selama penyimpanan lebih kecil dengan penambahan $\mathrm{H}_{2} \mathrm{O}_{2}$ pada proses penyempurnaan serat.

\section{UCAPAN TERIMA KASIH}

1. Kepada PT. South Pacific Viscose yang telah memberikan izin untuk melakukan percobaan dan pengujian (tahun 2006).

2. Kepada Ibu Dr. Noerati, S.Teks., MT selaku pembimbing penulis pertama yang telah memberikan izin kepada penulis untuk menulis ulang tugas akhir.

\section{DAFTAR PUSTAKA}

1. Djufri, Rasjid, dkk. Teknologi Pengelantangan, Pencelupan dan Pencapan, Institut Teknologi Tekstil. Bandung. 1973.

2. Eriningsih, Rifaida dan Theresia Mutia. Masalah Penguningan Pada Bahan Tekstil. Arena Tekstil No. 38. 2003.

3. Hermans, Physics and Chemistry of Cellulose Fibres. Elsevier Publishing Company Inc., New York, Amsterdam-London-Brussels. 1949.

4. Interox, A Bleacher Handbook. Jerman. 1970.

5. Lachapelle, R.C, dst. Using Hydrogen Peroxide in 100\% Chlorine Dioxide Bleaching Sequence. TAPPI Journal 75. 1992.

6. Marsh, JT., An Introduction to Textile Bleahing, Chapman and Hall Ltd., London, 1956.

7. Sastrosoeparno, Santoso. Teknologi Pembuatan Serat Rayon Viskosa Seri 1, Bandung, 2006.

8. Senior, D.J dan Ragauskas, A.J. Interaction of Hydrogen Peroxide and Chlorine Dioxide in ECF Bleaching. International Pulp Bleaching Conference Proceedings. TAPPI Press. Atlanta. 1996.

9. Soeprijono, dkk, Serat-serat Tekstil, Institut Teknologi Tekstil, Bandung. 1974.

10. Trotman, ER., Textile Scouring and Bleaching, Charles Griffin and Company Ltd., London. 1968.

11. Ulia, Hasnah., Alternatif Penggunaan Hidrogen Peroksida pada Tahap Akhir Proses Pemutihan Pulp. Medan. 2007. 